\title{
South Korea-U.S. free trade agreement will lower export barriers for California products
}

by Hyunok Lee and Daniel A. Sumner

The United States and South Korea negotiated a bilateral trade agreement in 2007. After final legislative approval, likely later this year, high tariffs on exports of most California agricultural products to South Korea will be gradually eliminated. Already, with the tariffs in place, South Korea ranks among the top six destinations for many California agricultural exports. More-open access to the South Korean market will create significant opportunities for major commodities produced in California such as almonds and dairy products.

$\mathrm{T}$ he Republic of Korea (South Korea) and the United States signed a free trade agreement (KORUS FTA) on April 1 , 2007. In 2010, they negotiated a few adjustments to the agreement designed to facilitate approval by each country's legislature. With strong support from the Obama administration, legislation implementing the agreement is likely to be passed in spring or summer 2011. (We refer to the Republic of Korea as South Korea; isolationist and communist North Korea is a separate country.)

When it is implemented, the agreement will lower the trade barriers between the two countries in all sectors of trade. However, although it will benefit other sectors of U.S business, agriculture was central to the negotiations, and potential gains for the United States center around agricultural exports. Unlike the United States, South Korea has maintained high trade barriers for agricultural goods. KORUS FTA would lower those barriers and provide important opportunities for U.S. agricultural exports to South Korea.

The United States is already South Korea's top supplier of agricultural products, worth $\$ 3.5$ billion in 2007. The South Korean economy is growing and

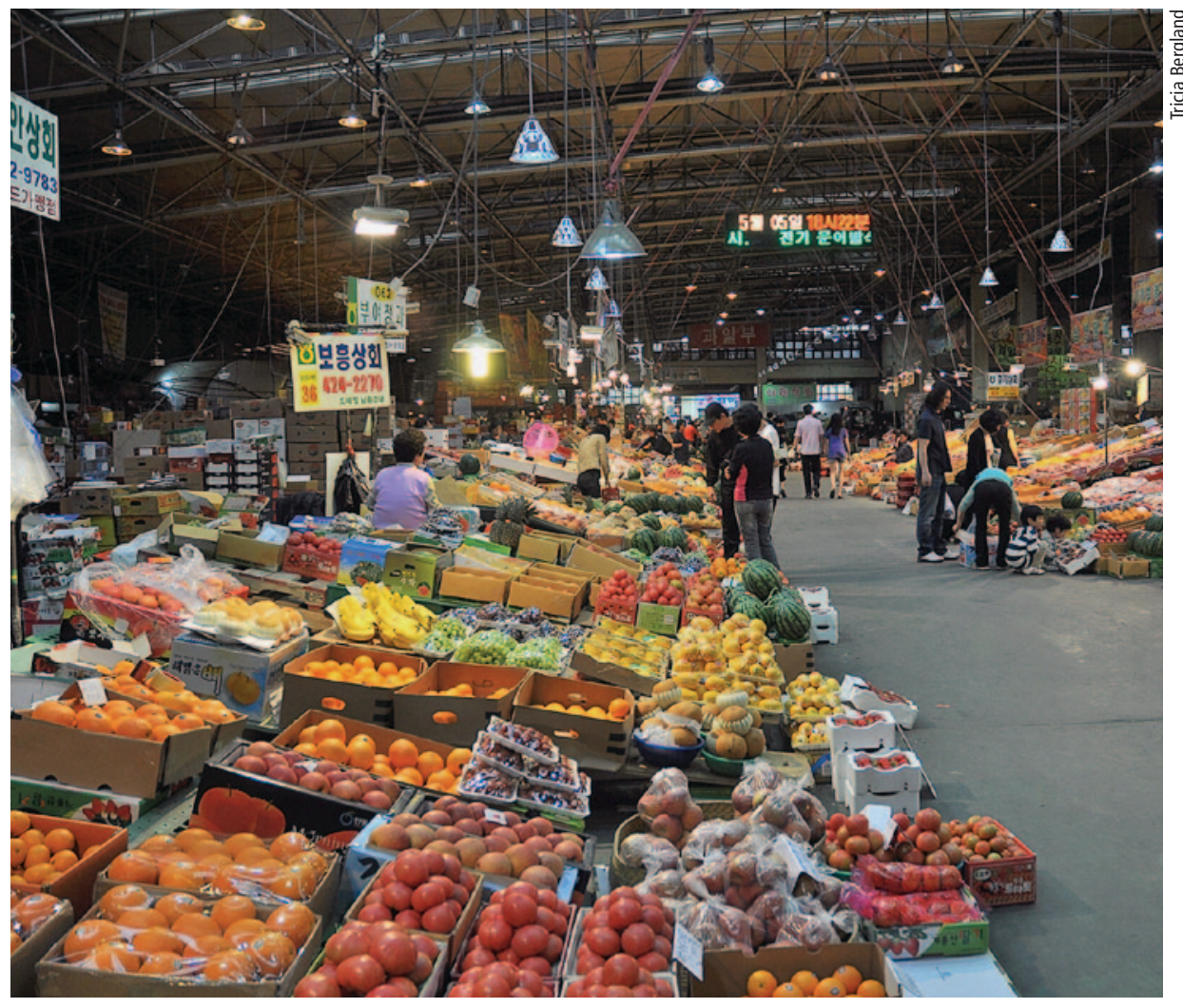

The United States has negotiated a free-trade agreement with South Korea that will greatly reduce tariffs on many California crops. The U.S. Congress is expected to pass the implementing legislation this year. Above, a wholesale produce market in Anyang City, south of Seoul.

already sizable; with about 50 million consumers, it has a per-capita income $(\$ 20,045$ in 2007) above that of many European countries. Prices for many commodities are high, and premiums are paid for high-quality produce.

The United States has many free trade agreements, most of them longstanding; South Korea has implemented fewer and they are relatively new. As of January 2011, the United States had free trade agreements in force with 17 countries including Canada, Mexico, Singapore, Central America-5 (Costa Rica, El Salvador, Guatemala, Honduras and Nicaragua), Israel, Australia, Chile, Jordan, Morocco, Dominican Republic, Oman, Peru and Bahrain (USTR 2011). South Korea has free trade agreements with Chile, Singapore, ASEAN-10 (Association of South East Asian Nations) and EFTA-4 (European Free Trade Association-4: Iceland, Liechtenstein, Norway and
Switzerland). The earliest South Korean free trade agreement was implemented in 2004.

KORUS FTA is especially significant for California agriculture because South Korea ranks among its top six export destinations (Matthews and Sumner 2008), and trade barriers for many agricultural products to South Korea are currently high. In many cases, major exports of California agriculture face tariffs of more than $30 \%$. For some products, including beef, citrus and tree nuts, significant exports are able to penetrate the South Korean market despite high tariffs. Because of the size of the South Korean economy and the height of pre-existing trade barriers, KORUS FTA is considered the most commercially significant free trade agreement that the United States has negotiated in nearly 20 years.

KORUS FTA has little potential to stimulate South Korean agricultural 
exports to the United States in competition with California products. U.S. agricultural tariffs are already low and production costs in South Korea are high, so few South Korean agricultural products can compete successfully in the U.S. market. Once KORUS FTA is implemented, our assessment is that it will stimulate more demand for U.S. products in South Korea, and the consequences for California agriculture will be slightly higher farm prices, increased agricultural output, additional employment and an expansion of the California agricultural economy past the farm gate.

This paper explores the importance of the South Korean export market for California agriculture and the nature of current trade barriers; shows the schedule for removing tariffs; and explains how the new tariffs arrangement will improve the competitive position of California agricultural exports relative to South Korean products and other countries' exports to South Korea.

\section{Korean agriculture and trade}

South Korea has changed phenomenally during the past half century, from an extremely poor, agrarian economy using 19th-century technology at best, to a wealthy, modern society at the cutting edge of applied science and technology. However, agriculture

\begin{tabular}{|c|c|c|}
\hline \multicolumn{3}{|c|}{$\begin{array}{l}\text { TABLE 1. Values of agricultural and } \\
\text { bilateral trade between the United States and } \\
\text { South Korea, } 2000 \text { and } 2007\end{array}$} \\
\hline & 2000 & 2007 \\
\hline & \multicolumn{2}{|c|}{$\$$ billions } \\
\hline \multicolumn{3}{|l|}{ World trade } \\
\hline \multicolumn{3}{|l|}{ United States } \\
\hline Exports & 51.3 & 89.9 \\
\hline Imports & 39.0 & 71.9 \\
\hline \multicolumn{3}{|l|}{ South Korea } \\
\hline Exports & 1.3 & 2.4 \\
\hline Imports & 6.8 & 13.3 \\
\hline \multicolumn{3}{|l|}{ Bilateral trade } \\
\hline $\begin{array}{l}\text { U.S. exports to South Korea } \\
\text { (South Korean imports from } \\
\text { United States) }\end{array}$ & 2.5 & 3.5 \\
\hline Share of U.S. exports (\%) & 5 & 4 \\
\hline $\begin{array}{l}\text { Share of South Korean } \\
\text { imports }(\%)\end{array}$ & 37 & 26 \\
\hline Sources: FAS 2009; KATI 2009. & & \\
\hline
\end{tabular}

has not been transformed to the same degree as the industrial and service economies. Protection from imports has kept much of agriculture insulated from competitive pressures. Farm size has remained small, far below average farm sizes in other industrial economies. Furthermore, with limited natural resources, South Korean agriculture has little potential to expand in a freer trade environment.

The United States is a major net agricultural exporter and South Korea is a major net importer, reflecting the relative competitiveness of agriculture in each country (table 1). Agricultural goods are especially important commodities in bilateral trade between the United States and South Korea. The South Korean market accounted for 5\% (in 2000) and 4\% (in 2007) of U.S. agricultural exports, consistently higher than the $4 \%$ (in 2000) and 3\% (in 2007) of U.S. general merchandise exports that went to South Korea. The
United States is the most important source of South Korean agricultural imports, enjoying a 26\% share in 2007. Coarse grain represented $24 \%$ of the U.S. share, followed by fruits, nuts and vegetables $(12 \%)$ and meat $(11 \%)$. In the past decade, U.S. market share in South Korea has declined, mainly due to the growth of competitors including China, Australia and Chile.

\section{California exports}

In 2007, the total value of all California agricultural exports to South Korea was almost \$400 million (table 2). South Korea was the sixth largest destination for California exports, with about $4 \%$ going to South Korea. For some products, South Korea was a much more important destination. Among all export commodities sent to South Korea, fresh oranges top the list, followed by rice, and beef and beef products. In 2007, the bulk of beef and beef products were hides and
TABLE 2. Value of California agricultural exports to South Korea by commodity, 2007

\begin{tabular}{|c|c|c|c|c|}
\hline \multirow[b]{2}{*}{ Commodity } & \multicolumn{2}{|r|}{ Exports* } & \multirow[b]{2}{*}{$\begin{array}{c}\text { Share of S. } \\
\text { Korean market }\end{array}$} & \multirow{2}{*}{$\begin{array}{c}\text { A/B } \\
\text { (rank among all } \\
\text { destinations) } \dagger\end{array}$} \\
\hline & $\begin{array}{l}\text { To South } \\
\text { Korea (A) }\end{array}$ & To all destinations (B) & & \\
\hline & \multicolumn{2}{|c|}{$\ldots \ldots \ldots \ldots \$$ millions $\ldots \ldots \ldots \ldots$} & \multirow{2}{*}{$\begin{array}{c}\% \\
4\end{array}$} & \\
\hline Total & 386.4 & 10,912 & & (6) \\
\hline Oranges & 55.0 & 260 & 21 & (2) \\
\hline Rice & 43.3 & 313 & 14 & (2) \\
\hline Beef, beef products & 40.5 & 199 & 20 & (2) \\
\hline Almonds & 35.6 & 1,879 & 2 & \\
\hline Walnuts & 35.2 & 444 & 8 & (4) \\
\hline Dairy products & 28.9 & 963 & 3 & \\
\hline Hay & 18.1 & 134 & 14 & (3) \\
\hline Wine & 15.8 & 816 & 2 & \\
\hline Cotton & 13.5 & 505 & 3 & \\
\hline Tomatoes, processed & 11.3 & 300 & 4 & \\
\hline Table grapes & 10.0 & 553 & 2 & \\
\hline Cherries & 8.5 & 97 & 9 & (3) \\
\hline Lemons & 8.4 & 169 & 5 & (4) \\
\hline Grape juice & 6.7 & 32 & 21 & (2) \\
\hline Raisins & 5.9 & 213 & 3 & \\
\hline Grapefruit & 5.8 & 79 & 7 & \\
\hline Kiwifruit & 2.5 & 14 & 18 & (3) \\
\hline Plums, dried & 2.3 & 175 & 1 & \\
\hline Pistachios & 2.2 & 364 & 1 & \\
\hline Lettuce & 1.8 & 274 & 1 & \\
\hline
\end{tabular}


TABLE 3. Value of South Korean imports and major competitors for selected commodities, 2007

\begin{tabular}{|c|c|c|c|c|}
\hline & $\begin{array}{l}\text { South } \\
\text { Korean } \\
\text { imports }\end{array}$ & $\begin{array}{l}\text { U.S. share } \\
\text { of South } \\
\text { Korean } \\
\text { imports }\end{array}$ & $\begin{array}{l}\text { Import share } \\
\text { of domestic } \\
\text { consumption* }\end{array}$ & $\begin{array}{l}\text { Major competitors' share of South } \\
\text { Korean imports }\end{array}$ \\
\hline & $\$$ millions & $\ldots \ldots \ldots$ & $\ldots \ldots$ & $\ldots \% \ldots \ldots \ldots \ldots \ldots \ldots \ldots \ldots \ldots$ \\
\hline Fruits (total) & 852 & 27 & n/at & $\begin{array}{l}\text { Philippines (30), China (9), Chile (7), } \\
\text { New Zealand (7), Brazil (5) }\end{array}$ \\
\hline Bananas & 171 & 0 & 100 & Philippines (100) \\
\hline Oranges, fresh & 108 & $93 \neq$ & 9.9 & $-\S$ \\
\hline Oranges, juice & 71 & 24 & 100 & Brazil (60) \\
\hline Kiwifruit, fresh & 70 & 8 & 100 & New Zealand (77), Chile (14) \\
\hline Pineapples & 68 & 0 & 100 & Philippines (98) \\
\hline Table grapes & 58 & 18 & 8.3 & Chile (82) \\
\hline Cherries, all & 36 & 91 & 100 & - \\
\hline Grape juice & 25 & 47 & 100 & Spain (26) \\
\hline Lemons & 11 & 77 & 100 & Chile (5), Italy (10) \\
\hline Apples, processed & 10 & 0 & 100 & China (50), Chile (2) \\
\hline $\begin{array}{l}\text { Strawberries, frozen } \\
\text { and processed }\end{array}$ & 10 & 26 & 3.7 & China (57), Mexico (5) \\
\hline Peaches, processed & 9 & 0 & 100 & China (44), South Africa (20), Greece (14) \\
\hline Grapefruit (incl. juice) & 9 & 74 & 100 & Japan (12) \\
\hline Raisins & 6 & 98 & 100 & - \\
\hline Olives & 3 & 1 & 1 & Spain (75), Italy (18) \\
\hline Prunes, dried & 2 & 98 & $\mathrm{n} / \mathrm{a}$ & - \\
\hline Peaches, juice & 1 & 83 & 100 & China (8) \\
\hline Pears, processed & 0.3 & 1 & 100 & China (48), Spain (18), South Africa (12) \\
\hline Pears, fresh & 0.1 & 83 & 0 & - \\
\hline Vegetables (total)ף & 466 & 14 & 11 & China (69), Japan (4), New Zealand (3) \\
\hline Red peppers & 85 & 0 & 15 & China (95) \\
\hline Carrots & 37 & 0 & $\mathrm{n} / \mathrm{a}$ & China (98) \\
\hline Tomatoes & 36 & 32 & 100 & China (42), Chile (10), Italy (9) \\
\hline Garlic & 32 & 0 & 12.8 & China (100) \\
\hline Pumpkins & 15 & 0 & $n / a$ & New Zealand (88) \\
\hline Onions & 13 & 6 & 3 & China (94) \\
\hline Broccoli & 11 & 0 & $\mathrm{n} / \mathrm{a}$ & China (100) \\
\hline Cucumbers & 9 & 47 & $\mathrm{n} / \mathrm{a}$ & China (41) \\
\hline Lettuce & 4 & 48 & $\mathrm{n} / \mathrm{a}$ & China (52) \\
\hline Tree nuts (total) & 76 & 94 & 93 & - \\
\hline Walnuts & 38 & 91 & 100 & Vietnam (9) \\
\hline Almonds & 35 & 100 & 100 & - \\
\hline Pistachios & 3 & 59 & 100 & Iran (37) \\
\hline $\begin{array}{l}\text { Dairy, beef and beef } \\
\text { products (total) }\end{array}$ & 1,856 & 28 & $\mathrm{n} / \mathrm{a}$ & Australia (45), New Zealand (15) \\
\hline Beef & 1,037 & 9 & 59 & Australia (73), New Zealand (16) \\
\hline Dairy products, all & 438 & 19 & $\mathrm{n} / \mathrm{a}$ & New Zealand (24), Australia (15) \\
\hline Hides and skins & 381 & 89 & $\mathrm{n} / \mathrm{a}$ & - \\
\hline \multicolumn{5}{|l|}{ Other } \\
\hline Cotton & 305 & 40 & 100 & Australia (13) \\
\hline Hay & 237 & 82 & $\mathrm{n} / \mathrm{a}$ & - \\
\hline Wine & 150 & 11 & $\mathrm{n} / \mathrm{a}$ & France (45), Chile (15) \\
\hline Rice & 137 & 31 & 5.4 & China (61), Thailand (8) \\
\hline Flowers & 68 & 1 & $\mathrm{n} / \mathrm{a}$ & China (31), Taiwan (30), Netherlands (18) \\
\hline
\end{tabular}

Sources: KATI 2009; KMAFF 2008.

* Some shares are based on quantity when values are not available (official South Korean data at the commodity level often includes only quantity).

† No domestic production statistics available, or commodity aggregation is not meaningful (e.g., dairy products).

‡ Discrepancy between South Korean and U.S. sources; U.S. figure was $\$ 85.4$ million.

$\S$ No major competitors.

१ी Lettuce imports are fresh; carrot and pumpkin imports are mostly fresh; pepper, cucumber and tomato imports are dried, frozen or preserved; other vegetables are mixed (for more detail, see Lee and Sumner 2009). skins. Before the collapse of exports in 2004 - caused by the discovery of a U.S. slaughter cow with bovine spongiform encephalopathy (BSE) or "mad cow" disease in December 2003 - beef was the most important export item shipped to South Korea from California. Other products that hold double-digit shares of the South Korean market are hay, grape juice and kiwifruit. While the value of almond and walnut exports is about equal, South Korea is a more important market for the California walnut industry than it is for almonds.

Processed tomatoes and lettuce are the only vegetables exported to South Korea, which is not a major vegetable-importing country (table 2). Vegetables accounted for less than 5\% of South Korea's total crop-based agricultural imports in 2007 (KMAFF 2008). Moreover, except for a few vegetables such as processed tomatoes, lettuce and cucumbers - China dominates the South Korean vegetable import market, with a $69 \%$ share; the United States is a distant second, with an $11 \%$ share (Lee and Sumner 2009).

KORUS FTA will give California suppliers a price advantage over suppliers from nations without a South Korean free trade agreement, and allow California suppliers to keep up with those from nations that have current or prospective agreements with South Korea. When South Korea's free trade agreement with Chile became effective on April 1, 2004, Chilean exports to South Korea grew substantially for kiwifruit, grape juice, lemons, processed tomatoes, wine and whey, which are all major California export products (Lee and Sumner 2009).

California's major international competitors for trade with South Korea are Chile for table grapes and wine (next to France); Spain for grape juice and olives; New Zealand for kiwifruit, beef and dairy; Australia for beef, dairy and cotton; Iran for pistachios; and China for strawberries, lettuce, garlic, red peppers, rice, flowers and processed tomatoes (table 3).

The potential for California producers to increase exports to South Korea when the market is opened also crucially depends on the competitiveness of South Korea's domestic producers. 


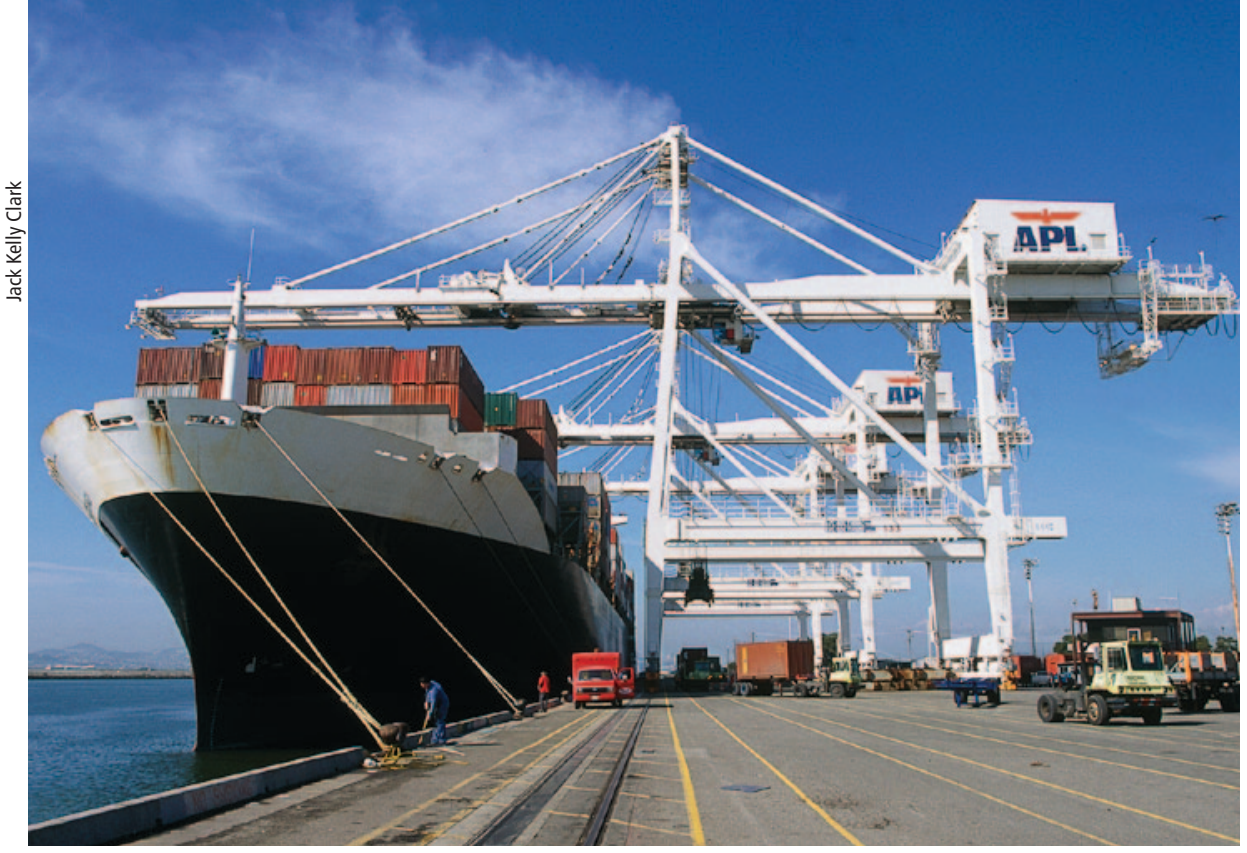

KORUS FTA will provide unrestricted market access for certain agricultural crops, phase out many tariffs and impose safeguard measures to protect some domestic crops during the transition. Above, a cargo ship is loaded at the Port of Oakland.

Imports to South Korea currently represent a small share of the domestic consumption of many major products, such as table grapes, fresh strawberries, fresh apples, lettuce and rice (table 3). Import tariffs for these products are high, about $45 \%$ in most cases. Fresh peaches and pears are an extreme example of the closed nature of the South Korean market for some products; South Korea has a sizable market for these fresh fruits, but almost no imports enter the country. Under the South Korea-Chile free trade agreement, preferential (lower) tariffs are applied for all trade between the two countries; however, pears are excluded, and no imports are allowed. The situation for processed fruits is different, with almost all coming from imports. Mostly, imports are low when domestic production is available. Only a few products - oranges, beef, some dairy and hay - are imported when there is also substantial domestic production, indicating that the overseas producers of these products are able to compete with domestic supplies despite sizable tariffs.

\section{Opening the South Korean market}

KORUS FTA defines four mechanisms for establishing better access for agricultural products: (1) the immediate opening of certain markets without restrictions, (2) the phase-out of tariffs over a specified number of years, (3) the expansion of tariff rate quotas (TRQs), with the phase-out of over-quota tariffs and (4) the imposition of safeguard measures (USTR 2008) (table 4). (Tariff rate quotas apply a relatively low tariff for an initial quantity - the "quota" amount - and then a higher over-quota tariff for any additional quantity of imports.) Safeguards will be imposed for some politically sensitive commodities to protect the domestic industry during the transition. Typically, a safeguard trigger level (either a quantity or price) is set, and once it is reached additional
6 Walnuts (shelled), off-season fresh oranges duties are assessed to control access to the market.

The impact of greater access to the South Korean market will critically depend on the levels of pre-existing tariffs, which vary by product (table 5). Importantly, KORUS FTA allows no additional access for rice, which has a quota allowed under a 1994 World Trade Organization agreement.

Citrus. South Korea is a major market for fresh oranges and other citrus from California, despite a current duty of $50 \%$. While the agreement lowers trade barriers considerably during the off-season, in-season imports (Sept. 1 to Feb. 29) will still be subject to tight tariff rate quotas. The limited access improvement for in-season oranges is designed to protect the domestic producers of mandarin oranges, which are almost identical to Satsumas and referred to as "Korean citrus" in the agreement. The initial duty-free tariff rate quota of 2,500 tons is equivalent to only $0.4 \%$ of Korean citrus produced in South Korea in 2007. Imported oranges are clear substitutes for Korean citrus during the in-season, which is why imports are limited by the $50 \%$ tariff. In addition to limiting imports of fresh oranges, South
TABLE 4. Access improvement for important agricultural products by general market access category upon implementation of KORUS FTA*

Immediate unrestricted opening: Asparagus, cabbage, celery, cucumbers, eggplants, shallots, spinach (fresh and frozen), tomato paste, cherries, olives, raisins, frozen orange concentrate, grape juice, wine, almonds, pistachios, coffee, cattle hides and skin, live livestock, feed whey

Tariff phase-out (numbers indicate years to complete)

2 Avocados, lemons, dried plums

5 Chinese cabbage, carrots (fresh and frozen), cauliflower, broccoli, peas, beanst, dried mushroomst, tomato juice, grapefruit, strawberries (frozen), orange juice, various fruit juices

4 Off-season table grapes

7 Tomatoes, ice cream, apricots

9 Strawberries

10 Artichokes, Brussels sprouts, preserved cucumbers, lettuce, fresh mushroomst, peaches, pears (excluding Asian pears), dates, persimmons, tangerine juice

12 Chicken meat, frozen onions, watermelon, various berries

15 Korean citrus, kiwifruit, walnuts (in shell), chestnuts, pine nuts, oak mushrooms (fresh and dried), beef offal

17 In-season table grapes

20 Asian pears

Duty-free tariff rate quota expansion with or without over-quota tariff phase-out: In-season fresh oranges, many dairy products

Safeguard quantity and duty: Garlic, onions, peppers, beanst, sweet potatoes, ginger, apples, beef, pork

Source: USTR 2008.

* Rice excluded from agreement.

† Some varieties excluded. 
Korea has a $144 \%$ tariff on Korean citrus and mandarins from other countries.

While not currently large, South Korean demand for fresh grapefruit, lemons and limes is growing. South Korea is becoming a major export market for California grapefruit and lemons because it does not produce these citrus fruits. Lower domestic prices - resulting from lower tariffs - will further increase demand.

Other fruits. For most fruits, access is improved under a simple tariff phaseout, but schedules to open the markets for apples, Asian pears and table grapes are more restrictive. These are the noncitrus fruits consumed widely in South Korea. The initial safeguard quantity for apples is 9,921 tons $(9,000$ metric tons), less than $2.5 \%$ of domestic riety favored by South Koreans, have a long period of market opening with the safeguard duty lasting 23 years (neither apples nor pears currently have access due to phytosanitary issues).

The South Korean market for grape products is substantial. In 2007, South production. Further, Fuji apples, the va-

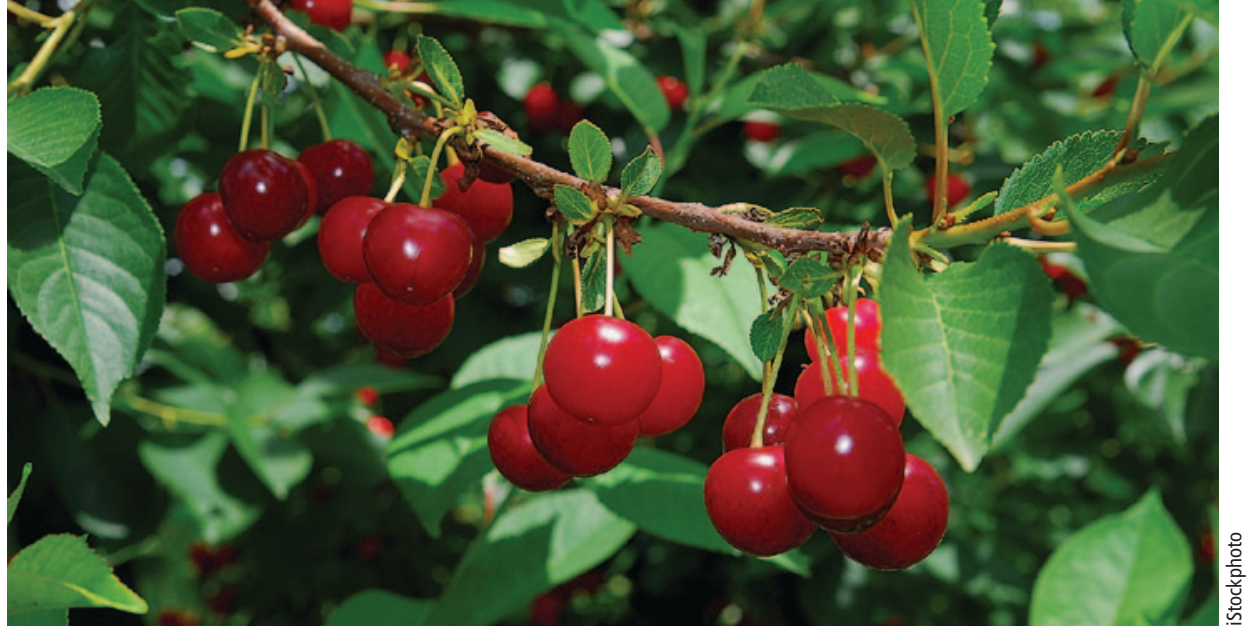

Cherries are the second largest fresh-fruit export from the United States to South Korea, with about $30 \%$ supplied by California. The elimination of a $24 \%$ tariff is expected to further expand this market.
Korea imported table grapes worth close to $\$ 60$ million. Table grapes do not face overall quantity restrictions, but seasonal import restrictions apply. Along with the immediate tariff reduction from $45 \%$ to $24 \%$, the tariff for off-season imports (Oct. 16 to April 30) phases out in 4 years, and the tariff for in-season imports phases out over 17 years. Chile and the United States (mostly California) dominate the South Korean grape import market. Chile currently holds $85 \%$, in part because its
TABLE 5. Current base tariffs on exports to South Korea for selected products

\begin{tabular}{|c|c|}
\hline Base tariff $(\%)$ & Product \\
\hline 1 & Cattle hides and skin \\
\hline \multirow[t]{2}{*}{8} & Almonds (shelled and in shell) \\
\hline & Tomatoes (paste) \\
\hline $18-20$ & Plums (dried), olive, casein \\
\hline $21-24$ & Raisins, cherries (fresh) \\
\hline \multirow[t]{3}{*}{$27-30$} & $\begin{array}{l}\text { Artichokes, Chinese cabbage, broccoli, cauliflower, Brussels sprouts, garlic (frozen and } \\
\text { pickled), peppers (frozen), onions (frozen), cucumbers (pickled), carrots (fresh, frozen, } \\
\text { preserved and dried) }\end{array}$ \\
\hline & Beef offal \\
\hline & $\begin{array}{l}\text { Lemons and limes, grapefruit (fresh and juice), wine, avocados, dates, pistachios, } \\
\text { walnuts (shelled) }\end{array}$ \\
\hline \multirow[t]{2}{*}{$36-40$} & Cheese \\
\hline & Beef (muscle cuts) \\
\hline \multirow[t]{3}{*}{$45-50$} & $\begin{array}{l}\text { Apricots, cherries (canned), peaches, strawberries, other berries, oranges, peaches } \\
\text { (preserved), juices (grape, apple, lemon, lime, peach, strawberry), walnuts (in shell) }\end{array}$ \\
\hline & Lettuce, tomatoes \\
\hline & Lactose, whey \\
\hline 54 & Orange juice (frozen concentrate) \\
\hline 89 & Butter \\
\hline $135^{*}$ & Onions (fresh and dried) \\
\hline 144 & Korean citrus and mandarins \\
\hline 176 & Skim and whole milk power \\
\hline 270 & Peppers (fresh and dried) \\
\hline $360 *$ & Garlic (fresh and dried) \\
\hline Source: USTR 2008. & 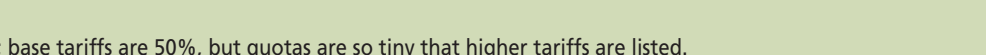 \\
\hline
\end{tabular}

exports are counter-seasonal to South Korean production. About $70 \%$ of U.S. table grape exports to South Korea are shipped during their off-season.

The import market for grape juice is also large, exceeding \$25 million in 2007, with the United States holding a $47 \%$ share. South Korean wine imports reached more than $\$ 150$ million in 2007, and U.S. wine, almost all from California, accounted for \$17 million. Under KORUS FTA, the 30\% tariff on U.S. wine will be eliminated immediately. South Korean raisin imports have reached close to $\$ 6$ million per year, and over $95 \%$ are shipped from California. The immediate elimination of the $45 \%$ tariff for grape juice and $21 \%$ tariff for raisins will allow a substantial reduction in domestic prices in South Korea.

U.S. fresh cherry exports to South Korea rank second highest among all U.S. fresh fruit exports. South Korean fresh cherry exports reached close to \$31 million in 2007, with 27\% supplied by California. South Korea produces almost no cherries, and the elimination of the $24 \%$ tariff is expected to expand the fresh cherry market even further. Among other fruits, strawberries and kiwifruit are promising for market expansion. Strawberries are probably the largest greenhouse crop, by value, in South Korea (no official information is available for greenhouse crops). Currently, no fresh strawberries enter the country, and over $70 \%$ of strawberry imports are frozen. China is the number-one supplier of frozen strawberry imports to South Korea, with about an $80 \%$ market share, and the rest of frozen strawberry imports are supplied by the United States and Mexico. Kiwifruit is relatively new to South 
Korean consumers, but imports have grown rapidly and totaled $\$ 70$ million in 2007. Kiwifruit imports are dominated by New Zealand, which has a $77 \%$ share, followed by Chile $(14 \%)$ and the United States (8\%); California supplies about half of the U.S. exports.

Tree nuts. California tree nuts have a strong presence in the South Korean market. Almond and walnut exports are already substantial (about \$35 million each). In South Korea, there is no domestic tree nut industry to offer competition. The United States is the only supplier for almonds and has more than a $90 \%$ share in the walnut market. All U.S. walnut and almond exports to South Korea are supplied exclusively by California. The current $8 \%$ almond tariff will be eliminated, and in-shell and shelled walnut tariffs, as high as $45 \%$, will be phased out over 6 and 15 years, respectively. Pistachios are relatively new in South Korea and not widely consumed. U.S. exports of pistachios (all from California) are currently small, but with immediate elimination of the $30 \%$ tariff, the potential will be large for California growers.

Vegetables. South Korean tariffs on vegetables will be eliminated either immediately or phased out over time, except for a few sensitive products for which safeguard restrictions apply. We only discuss the vegetables that have significant import value or potential as exports from California. Vegetable trading in South Korea is dominated by China, except for a few products such as fresh pumpkins (New Zealand supplies about $88 \%$ ), pickled cucumbers (supplied almost solely by the United States) and fresh lettuce (the United States holds about a 50\% market share, and California supplies about $41 \%$ of U.S. exports).

With a $45 \%$ tariff, U.S. exports of lettuce were $\$ 4.4$ million in 2007. Imports constitute a small share of the domestic South Korean market, which is valued at $\$ 200$ million. California lettuce competes mostly with off-season, high-cost greenhouse lettuce in South Korea and has substantial export growth potential under the 10-year tariff phase-out. Other fresh, leafy vegetables such as spinach are favored by Korean consumers and also have potential for substantial export growth.

For a few sensitive products the agreement allows gradual access through 18-year phase-outs, with safeguard restrictions. Garlic, onions and red peppers are important ingredients in the South Korean diet and among the major crops in Korean agriculture. The

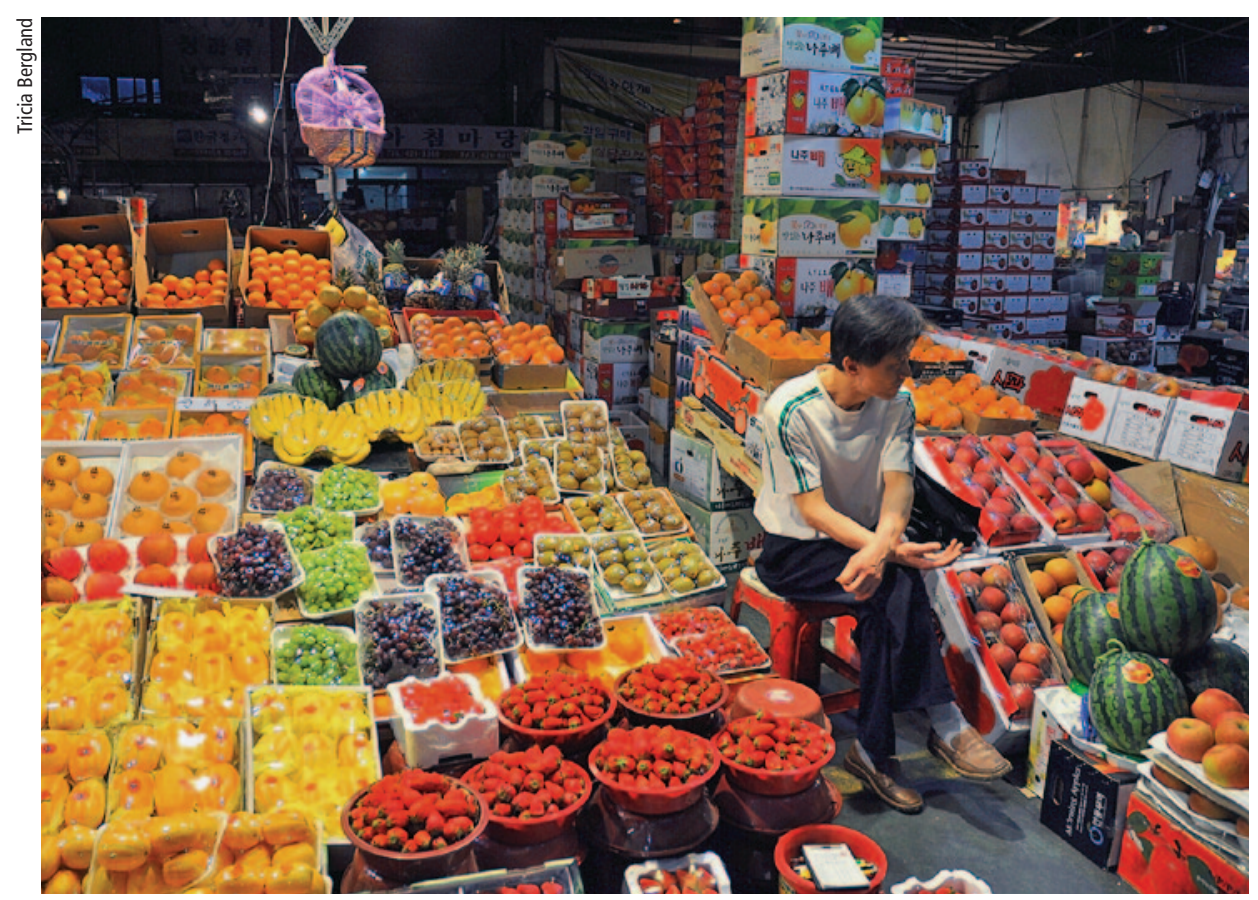

Under the free trade agreement, tariffs will be eliminated or phased out for many fruits exported by California growers to South Korea, including watermelon, table grapes and oranges. Safeguard duties and seasonal import restrictions will also apply to some fruits.

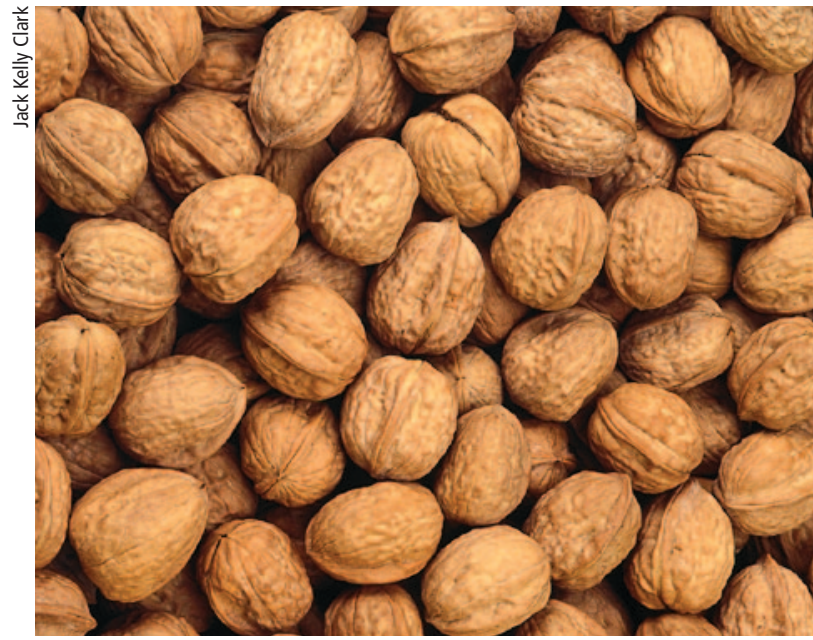

California growers provide all walnuts shipped from the United States to South Korea, which has no tree nut industry. In-shell walnut tariffs of up to $45 \%$ will be phased out over 6 to 15 years.

initial safeguard quantities for these products are tiny. They double only after 15 years, and the safeguard duties will remain prohibitive.

Base tariffs for these sensitive products differ significantly depending on the way the product is prepared. While fresh and dried garlic have a base tariff of $360 \%$, frozen garlic has a tariff of only $27 \%$. Predictably, two-thirds of garlic imports are frozen and over 70\% of red chili pepper imports, which have a relatively low tariff of $27 \%$, are also frozen.

Beef and related products. KORUS FTA imposes safeguard restrictions on U.S. beef imports. Beef products are the number-one agricultural import into South Korea by value, exceeding $\$ 1$ billion in 2007. South Korea became an important market for U.S. beef after its beef market was opened in 2001. The United States had the largest share of imports in December 2003, when South Korea banned U.S. beef following detection of the BSE case in the United States (South Korea accounted for 34\% of California beef exports in 2003). Since then, Australia and New Zealand have replaced the United States, together supplying more than $90 \%$ of Korean imports.

The United States resumed supplying beef to South Korea in 2007. However, recapturing the market now depends on U.S. competition with Australia and New Zealand as well as domestic producers. Australia 
